\title{
Karakteristik Edible Film Hasil Kombinasi Pati Biji Alpukat (Persea Americana Mill.) dan Pati Jagung (Amilum maydis) \\ Ulum M. ${ }^{1}$, Mu'tamar MFF ${ }^{2}$, Asfan ${ }^{3}$ \\ Teknologi Industri Pertanian, Universitas Trunojoyo Madura \\ mfuadfm@gmail.com
}

\begin{abstract}
ABSTRAK
Edible film merupakan lapisan tipis yang digunakan untuk melapisi makanan (coating), dan berfungsi sebagai pembawa bahan tambahan pangan. Penggunaan pati bijialpukat dalam pembuatan edible film memberi nilai tambah pada limbah biji alpukat. pati biji alpukat terdapat kandungan amilosa sebanyak 43,3 \%, sedangkan pati jagung digunakan karena sifat higroskopisnya dan mengandung amilosa 27\%.Tujuan dari penelitian ini mengetahui karakteristik edible film dari pati biji alpukat dan pati jagung dan menentukan hasil perlakuan terbaik dengan metode CPI (Composite Performance Index) terhadap produk edible film menggunakan bahan dasar pati biji alpukat dan pati jagung. Penelitian ini menggunakan rancangan acak lengkap (RAL) dengan 2 faktor perlakuan dan diulang sebanyak 3 kali, sehingga total ada 36 unit perlakuan, perlakuan penelitian ini mengkombinasikan pati biji alpukat $(Y)$ sebanyak 4 perlakuan yaitu 10, 20, 30, dan $40 \%$ dari pati jagung (X) yang di kombinasikan 4, 6, dan 8 gram. Parameter penelitian meliputi uji ketebalan, uji kuat tarik dan uji elongasi. Hasil Penelitian menunjukan karakteristik fisik Edible film pada penggunaan pati jagung (4 gr, $6 \mathrm{gr}$ dan $8 \mathrm{gr}$ ) dan pati biji alpukat (10\%, 20\%,30\%, dan 40\%) menghasilkan ketebalan 0,114-0,125 mm, kuat tarik $772,860-1018,233 \mathrm{~N} / \mathrm{cm}^{2}$, dan elongasi $9,032-$ $11,476 \%$. Hasil pemilihan perlakuan terbaik menggunakan CPI didapatkan bahwa perlakuan jagung $8 \mathrm{gr}$ + pati biji alpukat 2,4 gr menjadi perlakuan terbaik dengan nilai ketebalan 74,19 $\mathrm{mm}$, kuat tarik 223,25 N/cm² dan elongasi $513,75 \%$.
\end{abstract}

Kata kunci : Edible Film, Pati Jagung dan Pati Biji Alpukat.

\section{ABSTRACT}

Edible film is a thin layer used to coat food (coating), and serves as a carrier of food additives. The use of avocado seed starch in making edible films adds value to avocado seed waste. Avocado seed starch contained 43.3\% amylose content, while corn starch was used because of its hygroscopic properties and contained $27 \%$ amylose. The purpose of this study is to determine the characteristics of edible films from avocado starch and corn starch and determine the best treatment results by CPI method (Composite Performance Index) of edible film products using basic ingredients of avocado seed starch and corn starch. This study used a completely randomized design (CRD) with 2 treatment factors and repeated 3 times, so that a total of 36 treatment units, the treatment of this study combined avocado seed starch $(Y)$ of 4 treatments, namely 10,20,30, and $40 \%$ of corn starch $(X)$ combined 4,6 , and 8 grams. The research parameters included thickness test, tensile strength test and elongation test. The results showed the physical characteristics of Edible film on the use of corn starch $(4 \mathrm{~g}, 6 \mathrm{~g}$ and $8 \mathrm{~g}$ ) and avocado seed starch (10\%, 20\%,30\%, and 40\%) resulting in a thickness of 0.114 - $0.125 \mathrm{~mm}$, tensile strength $772,860-1018,233 \mathrm{~N} / \mathrm{cm} 2$, and elongation 9,032 - 11,476\%. The results of the selection of the best treatment using $\mathrm{CPI}$ showed that the corn treatment of $8 \mathrm{gr}$ + avocado seed starch 2.4 grams became the best treatment with a thickness value of 74.19 $\mathrm{mm}$, tensile strength $223.25 \mathrm{~N} / \mathrm{cm} 2$ and elongation of $513.75 \%$.

Keywords: Edible Film, Corn Starch and Avocado Seed Starch. 


\section{PENDAHULUAN}

Buah alpukat merupakan salah satu jenis buah yang digemari oleh masyarakat Indonesia, bagian buah alpukat yang bisa dikonsumsi adalah dagingnya, biji dan kulit alpukat biasanya terbuang. Limbah biji alpukat sering kali dijumpai di tempat industri pengolahan buah seperti penjualan jus. Berdasarkan Data Statistik Nasional Pertanian Republik Indonesia, tingkat produksi buah alpukat pada tahun 2013 yaitu 289.893 ton sedangkan pada tahun 2014 relatif meningkat dengan produksi 307.318 ton.

Biji alpukat belum dimanfaatkan secara maksimal, sehingga perlu adanya penelitian mengenai biji alpukat. Oleh karena itu, salah satu pemanfaat biji alpukat sebagai Inovasi yang bisa dilakukan untuk mengurangi penggunaan plastik dengan membuat edible film, kemasan makanan terbuat dari pati bersifat biodegradeble yang aman dan dapat terdegradasi, terurai dan hancur oleh organisme hiduplainnya yang berasal dari alam. Edible film dapat memecahkan permasalahan lingkungan. Bahan utama pembuatan edible film yaitu pati, keberadaan pati di Indonesia sangat melimpah dan beragam (Setiani et al. 2013). Pati yang digunakandalam penelitian yaitu pati biji alpukat dan pati jagung.
Pati jagung di dapat dari biji jagung yang diekstrak dengan tahap penghancuran biji melalui proses penggilingan, pemisahan kulit dan perendaman menggunakan air panas, kemudian penghancuran, pemisahan endapan, perendaman endapan ditambahkan natrium hidroksida dan air, pengeringan setelah itu pengayakan (Rabitan 1998 dalam Aini dan Haeni 2008).

Penggunaan pati biji alpukat dalam penelitian ini, karena memanfaatkan limbah biji alpukat secara maksimal, memberi nilai tambah pada limbah biji alpukat dan biji alpukat memiliki kandung amilosa yang tinggi. Pati biji alpukat terdapat kandungan amilosa sebanyak 43,3\% (Winarti dan Purnomo 2006 dalam Lubis 2008). Pati yang mengandung amilosa tinggi dapat dibuat menjadi edible film, menurut krisna (2011) dalam Yusdiandani et al. (2016) Amilosa adalah salah satu komponen yang paling berperan menentukan sifat edible film, sebab amilosa memiliki konsentrasi tinggi yang dapat membentuk gel serta menghasilkan lapisan tipis (film) lebih baik dari pada amilopektin. Pembuatan edible film dapat memecahkan permasalahan lingkungan. Bahan utama pembuatan edible film yaitu pati, keberadaan pati di Indonesia sangat melimpah dan beragam (Setiani et al. 2013). Pati yang 
digunakandalam penelitian yaitu pati biji alpukat dan pati jagung.

\section{Tujuan Penelitian}

Adapun tujuan penelitian ini yakni Mengetahui karakteristik edible film dari pati biji alpukat dan pati jagung dan Menentukan hasil perlakuan terbaik dengan metode CPI (Composite Performance Index) terhadap produk edible film menggunakan bahan dasar pati biji alpukat dan pati jagung.

\section{TINJAUAN PUSTAKA}

Edible film di definisikan sebagai lapisan tipis yang melapisi suatu bahan pangan dan layak dimakan, digunakan pada makanan dengan cara pembungkusan. Edible film juga dapat digunakan untuk memperbaiki kualitas makanan, memperpanjang massa simpan, meningkatkan efisiensi ekonomis, menghambat perpindahan uap air (Robertson 1992).

Edible film memiliki komponen penyusun, dengan pembuatan lapisan yang melapisi bahan pangan yang layak dimakan. Komponen penyusun edible film mempengaruhi secara langsung bentuk morfologi maupun karakteristik pengemasan yang dihasilkan. Komponen yang ada dalam penelitihan pembuatan edible film yaitu:

Pati salah satu polimer yang bisa digunakan dalam proses pembuatan edible film, pati sering digunakan dibidang industri pangan sebagai biogradeble film untuk menggantikan polimer plastik karena ekonomis, juga bisa diperbarui dan memberikan karakteristik film yang baik (Bourtoom 2007 dalam Basuki et al. 2014) Ada dua pati yang digunakan dalam penelitihan ini, yaitu Pati Jagung dan Pati biji alpukat. Komponen yang harus ada dalam pembuatan edible film adalah hidrokoloid, salah satunya protein berasal dari jagung. Kemampuan pati jagung menyerap air sangat besar, karena molekul pati jagung mengandung gugus hidrosil (Kusumawati dan Widya 2013).

Tabel. 2.1. Komposisi Kimia dan Sifat-sifat dari Pati Biji Alpukat.

\begin{tabular}{lll}
\hline No & \multicolumn{1}{c}{ Komponen } & Jumlah \\
\hline 1 & Kadar Air & $10,2 \%$ \\
2 & Kadar Pati & $80,1 \%$ \\
3 & ${ }^{*}$ Amilosa & $43,3 \%$ \\
4 & ${ }^{*}$ Amilopektin & $37,7 \%$ \\
5 & Serat Kasar & $1,21 \%$ \\
6 & Rendemen Pati & $21,3 \%$ \\
7 & Warna & Putih Coklat \\
8 & Kehalusan Granula & Halus \\
\hline
\end{tabular}

Sumber: Winarti dan Purnomo (2006) dalam Lubis (2008). 
Adapun komposisi biji alpukat dapat dilihat pada tabel 2.2.

Plasticizer

berfungsi

sebagai bahan dasar pembentukan film yang dapat meningkatkan fleksibilitas dan plastisitas film, plasticizer merupakan subtansi tidak mudah menguap yang memiliki titik didih tinggi, apabila dilakukan penambahan ke material lainnya bisa mengubah sifat fisik atau sifat mekanik material tersebut (Ulfah dan Nugraha 2014). Karagenan adalah polimer hidrofik berupa polisakarida sulfat yang dapat diekstrak dari rumput laut merah (Rhodophyceae) (Milani dan Maleki 2012). Karagenan membentuk edible film dengan mengabungkan atau mengikat silang rantai-rantai polimer sehingga terbentuk suatu jala tiga dimensi bersambung, jala tiga bersambung ini merupakan matrik utama pembuatan edible film. Matriks ini sifatnya kaku dan kuat, namun terdapat ruang kosong, ruang kosong inilah bahan pembentukan edible film yang lain untuk mengisinya (Syamsuar 2007 dalam Santoso et el. 2013).

\section{METODE PENELITIAN Waktu dan Tempat}

Penelitian dilaksanakan pada bulan Januari-Maret 2018 bertempat di Laboratorium Teknologi Industri Pertanian, Fakultas Pertanian, Universitas Trunojoyo Madura.

\section{Alat dan Bahan \\ Penelitihan pembuatan edible film menggunakan alat} seperti kain saring, beaker gelas, cabinet dryer, loyang, pipet tetes, gelas ukur, hot plate, spatula, blender, erlenmeyer, timbangan analitik, penggaris, kertas label, jangka sorong digital,ayakan 60 mesh dan tekstur analyzer. Penelitihan pembuatan edible film menggunakan bahan-bahan seperti pati jagung, pati biji alpukat, gliserol, aquades, natrium metabisulfit dan karagenan.

\section{Metode Peneltian}

Penelitian ini menggunakan rancangan acak lengkap (RAL) dengan 2 faktor perlakuan dan diulang sebanyak 3 kali, sehingga total ada 36 unit perlakuan, Perlakuan ini mengacu pada (Yudiandaniet al.2016).

Tabel 3.1. Rancangan Acak Lengkap Pengaruh Pati Biji Alpukat dan Pati Jagung Pada Karakteristik Edible Film.

\begin{tabular}{llll}
\hline \multicolumn{1}{c}{$\boldsymbol{y} / \boldsymbol{x}$} & $\mathrm{x} 1$ & $\mathrm{x} 2$ & $\mathrm{x} 3$ \\
\hline $\mathrm{y} 1$ & $\mathrm{x} 1 \mathrm{y} 1$ & $\mathrm{x} 2 \mathrm{y} 1$ & $\mathrm{x} 3 \mathrm{y} 1$ \\
$\mathrm{y2}$ & $\mathrm{x} 1 \mathrm{y2}$ & $\mathrm{x} 2 \mathrm{y} 2$ & $\mathrm{x} 3 \mathrm{y} 2$ \\
$\mathrm{y3}$ & $\mathrm{x} 1 \mathrm{y3}$ & $\mathrm{x} 2 \mathrm{y3}$ & $\mathrm{x} 3 \mathrm{y3}$ \\
$\mathrm{y4}$ & $\mathrm{x} 1 \mathrm{y} 4$ & $\mathrm{x} 2 \mathrm{y} 4$ & $\mathrm{x} 3 \mathrm{y} 4$ \\
\hline
\end{tabular}


Perlakuan penelitian ini mengkombinasikan pati biji alpukat $(Y)$ sebanyak 4 perlakuan yaitu $10,20,30$, dan $40 \%$ dari pati jagung $(X)$ yang di kombinasikan 4,6 , dan 8 gram.

\section{Prosedur Kerja}

Pembuatan edible film ini menggunakan beberapa tahap untuk membuat edible film seperti pembuatan pati biji alpukat serta pembuatan edible film. Prosedur kerja pada penelitihann ini dapat dilihat pada Gambar 3.1. Tahapan untuk membuat edible film sebagai berikut:

\section{Pati Biji Alpukat}

Pembuatan pati biji alpukat yang pertama yaitu menyediakan bahan seperti biji alpukat $(2 \mathrm{~kg}$ ), natrium metabisulfit (4000 ppm) pada $\mathrm{pH}$ netral selama 24 jam. Rasio biji alpukat dan larutan perendam 1:5 $(\mathrm{g} / \mathrm{ml})$. Setelah itu biji alpukat diblender sampai halus sehingga menghasilkan slurry yang kemudian disaring dengan kain saring sehingga meniggalkan endapan, selanjutnya endapan dioven pada suhu $50^{\circ} \mathrm{C}$ selama 6 jam kemudian diayak menggunakan ayakan 60 mesh. Perlakuan ini memacu pada penelitan (Yudiandani et al. 2016) yang berjudul pemanfaatan biji alpukat (Persea Americana Mill.) untuk pembuatan Edible Film.

\section{Pembuatan Edible Film}

Pembuatan edible film mengacu pada penelitian Yudiandani et al. (2016) yaitu menimbang bahan pati jagung dan pati biji alpukat dengan perbandingan yang sudah ditentukan, lalu ditambahkan gliserol $1 \mathrm{ml}$, karagenan 0,8 gr sekaligus menambahkan aquades sampai volume total $100 \mathrm{ml}$, setelah pencampuran bahan, kemudian dipanaskan dengan suhu $95^{\circ} \mathrm{C}$ sampai bahan menjadi bubur selulosa. Tuangkan adonan ke dalam cawan petri sebanyak 15 $\mathrm{ml}$. Kemudian adonan dikeringkan dalam oven selama 8 jam dengan suhu $65^{\circ} \mathrm{C}$, setelah itu terbentuklah bioplastik/ Edible film dan dilakukan implementasi sekaligus pengujian.

Pengamatan yang dilakukan pada Edible film adalah ketebalan, elongasi, dan kuat tarik.

\section{Ketebalan Edible film (mm)}

Penambahan pati berpengaruh nyata terhadap ketebalan edible film, semakin tinggi penambahan pati maka ketebalan edible film semakin meningkat (Amaliya dan Widya 2014). Tingginya penambahan pati biji alpukat dapat dilihat dari seberapa pengaruh padatan yang terlarut, apabila padatan terlarut meningkat maka adonan yang di oven kemudian dicetak membentuk edible film dengan volume yang semakin meningkat juga. Volume yang meningkat dengan cetakan edible film yang sama akan menghasilkan edible film yang semakin tebal (Yudiandaniet al. 2016). 
Parameter ketebalan film menggunakan ukuran (Jangka Sorong Digital Caliper 0-300 $\mathrm{mm}$ ).Nilai ketebalan yang diperoleh merupakan rataan dari pengukuran pada lima tempat yang berbeda (Bourtoom 2008 dalam Nathalya 2015).

Kuat Tarik (Tensile Strenght) $\left(\mathrm{N} / \mathrm{cm}^{2}\right)$

Kuat tarik adalah tarikan maksimum yang dapat dicapai edible film sebelum putus.

Pengukuran kuat tarik bertujuan untuk mengetahui besarnya gaya merenggang atau memanjang yang dicapai tarikan maksimum pada satuan luas area plastic (Purwanti 2010). Uji kuat tarik dan Elongasi menggunakan mesin texture analyzer (TAXT Plus, Stable Micro System, UK) menggunakan tensile grips TA96B. Menguji kuat tarik edible film dengan cara memotong sampel panjang $5 \mathrm{~cm} \times 1 \mathrm{~cm}$ kemudian dimasukkan dalam tensile grips TA-96 B lalu didapatkan data nilai kuat tarik (Sousa et.al. 2010 dalam Darmawan 2017). Kuat tarik (tensile strength) dapat dihitung menggunakan persamaan :

$$
\sigma=\frac{F}{A}
$$

Keterangan:

$\sigma=$ Kuat putus bahan (MPa)

$\mathrm{F}=$ Beban pada saat putus (kgms

2 atau $\mathrm{N}$ )

$A=$ Luas penampang $\left(\mathrm{m}^{2}\right)$

Kemoloran

(Break

Strain/Elongation) \%
Penambahan pati jagung mengakibatkan tingkat kemoloran edible film, karena pati jagung memiliki sifat elastis dan tidak mudah putus. Pati yang memiliki kadar amilosa dan plasticizer berupa gliserol tinggi menyebabkan persen elongasi edible film tinggi dan kuat, kadar amilopektin berpengaruh untuk menstabilkan dan mengelastiskan edible film (Putra 2013 dalam Amaliya dan Widya 2014).

Beberapa

peneliti

melakukan

penelitian

menggunakan pati jagung juga menggunakan pati biji alpukat diantaranya (Dyah dan widya 2013) mengkaji karakteristik fisik dan kimia edible film pati jagung yang diinkorporasi dengan perasan temu hitam, sedangkan (Yudiandaniet al. 2016) mengkaji pemanfaatan biji alpukat (persea Americana Mill.) untuk pembuatan edible film. Pengujian elongasi melakukan pengambilan sampel yang dipotong dengan ukuran panjang $5 \mathrm{~cm} X 1 \mathrm{~cm}$, sampel diuji menggunakan Tensile Strength didapatkan saat tercapainya tarikan maksimum hingga edible putus (Purwanti 2010). Adapun menghitung elongasi menggunakan rumus:

$$
\varepsilon=\frac{\text { Panjang patah }}{\text { panjang awal }} \times 100 \%
$$

\section{CPI (Composite Performance Index)}

CPI merupakan indeks gabungan yang dapat digunakan 
untuk menentukan peringkat atau penilaian dari berbagai alternatif (i) berdasarkan beberapa kriteria (j) (Rangkuti 2009). Menentukan perlakuan terbaik dengan metode CPI dikarenakan bisa mentransformasikan skala yang berbeda menjadi nilai yang seragam sehingga didapatkan nilai alternatif. Nilai alternatif yang sudah berurut membantu dalam pengambilan keputusan sehingga memiliki penilaian yang sama terhadap satu alternatif (Fajarini et al. 2015).

CPI digunakan untuk pengambilan keputusan dengan banyak kriteria dan arah, rentang dan besaran untuk masingmasing kriteria tidak sama (Santoso 2016). Adapun teknik dalam penentuan pengambilan CPI seperti berikut:

$A_{i j}=\left(X_{i j}(\min ) / X_{i j}(\min )\right) \times 100$

$\left.A_{(i+l . j)}=\left(X_{(i+l . j . j}\right) / X_{i j}(m i n)\right) \times 100$

$\mathrm{lij}_{\mathrm{ij}}=\mathrm{A}_{\mathrm{ij}} \times \mathrm{P}_{\mathrm{j}}$

$\mathrm{li}=\sum_{j=1}^{n} I i j$

\section{Analisis Data}

Data hasil dari penelitian diolah menggunakan Software SPSS22.0. Selanjutnya dilakukan analisis menggunakan metode ANOVA untuk mengetahui beda nyata dari setiap perlakuan, apabila terdapat beda nyata $5 \%$ $(P<0,05)$ maka akan dilanjutkan uji Duncan.

\section{HASIL DAN PEMBAHASAN}

\section{Ketebelan Edible film}

Pengujian ketebalan edible film bertujuan untuk mengetahui kualitas, parameter ketebalan edible film yang berpengaruh terhadap penggunaan melapisi dan mengemas produk.

Tabel 4.3 menunjukkan nilai uji karakteristik ketebalan edible film yang sesuai dengan perlakuan. Adapun nilai yang didapat menurun, hal ini dipengaruhi oleh pati jagung yang mempunyai sifat hidrokopis

Tabel 4.3 Nilai Ketebalan Edible Film dari Beberapa Variasi Pati Jagung.

\begin{tabular}{cc}
\hline Pati Jagung & Ketebalan Edible film \\
\cline { 2 - 2 } & Rata-rata $(\mathrm{mm})$ \\
\hline $4 \mathrm{gr}$ & $0,1467^{\mathrm{b}}$ \\
$6 \mathrm{gr}$ & $0,1083^{\mathrm{b}}$ \\
$8 \mathrm{gr}$ & $0,1033^{\mathrm{a}}$ \\
\hline
\end{tabular}

Keterangan : Nilai rata-rata yang ditandai dengan huruf yang sama menunjukkan tidak berbeda nyata pada taraf $5 \%$ Uji Duncan. 
Tabel 4.4 Nilai Ketebalan Edible Film dari Beberapa Variasi Pati Biji Alpukat

\begin{tabular}{cc}
\hline Pati Alpukat & Ketebalan Edible film \\
\cline { 2 - 2 } & Rata-rata $(\mathrm{mm})$ \\
\hline $10 \%$ & $0,0944^{\mathrm{a}}$ \\
$20 \%$ & $0,1067^{\mathrm{ab}}$ \\
$30 \%$ & $0,1156^{\mathrm{b}}$ \\
$40 \%$ & $0,1611^{\mathrm{c}}$ \\
\hline
\end{tabular}

Keterangan : Nilai rata-rata yang ditandai dengan huruf yang sama menunjukkan tidak berbeda nyata pada taraf 5\% Uji Duncan.

Tabel 4.6. Nilai Kuat Tarik Edible Film dari Beberapa Variasi Pati Biji Alpukat

\begin{tabular}{cc}
\hline Pati Biji Alpukat & Tensile Strenght Edible film \\
\cline { 2 - 2 } & Rata-rata \\
\hline $10 \%$ & $464,1111^{\mathrm{a}}$ \\
$20 \%$ & $914,3711^{\mathrm{b}}$ \\
$30 \%$ & $992,6659^{\mathrm{b}}$ \\
$40 \%$ & $1211,0381^{\mathrm{b}}$ \\
\hline
\end{tabular}

Keterangan : Nilai rata-rata yang ditandai dengan huruf yang sama menunjukkan tidak berbeda nyata pada taraf 5\% Uji Duncan.

(kemampuan menyerap air) yang tinggi, semakin tinggi penambahan pati jagung maka ketebalan edible film menurun. Hal ini mempengaruhi jumlah total padatan yang dilarutkan dan pengambilan sampel yang menggunakan pipet.

Tabel 4.4 menunjukkan nilai uji karakteristik ketebalan edible film naik, sesuai dengan penelitian yang dilakukan oleh Yudiandani et al. (2016) tingginya pati maka ikatan polimer edible film yang terbentuk semakin tebal setelah peristiwa Retrogradasi. Pendapat ini sama dengan Warkoyo et al. (2014) yang menyatakan bahwa semakin banyak penambahan jumlah pati maka polimer penyusun matriks film meningkat.

\section{Kuat Tarik Edible film}

Pati biji alpukat memberikan pengaruh terhadap nilai tensile strenght edible film yang dihasilkan. Semakin banyak pati biji alpukat yang diberikan nilai tensile strength edible film semakin tinggi pula. Adapun hasil kuat tarik dapat dilihat pada tabel 4.6.

Tabel 4.6 dapat diketahui bahwa nilai rata-rata tensile strenght meningkat, sehingga edible film yang dibuat memiliki sifat ikatan sekunder antara rantai polimer terhadap gaya luar yang tidak rapuh, seperti halnya yang dilakukan oleh Druchta dan 
Tabel 4.9. Nilai Elongasi Edible Film dari Beberapa Variasi Pati Jagung.

\begin{tabular}{cc}
\hline Pati Jagung & Elongasi Edible film \\
\cline { 2 - 2 } & Rata-rata \\
\hline $4 \mathrm{gr}$ & $7,6472^{\mathrm{a}}$ \\
$6 \mathrm{gr}$ & $6,1467^{\mathrm{a}}$ \\
$8 \mathrm{gr}$ & $16,9681^{\mathrm{b}}$ \\
\hline
\end{tabular}

Keterangan : Nilai rata-rata yang ditandai dengan huruf yang sama menunjukkan tidak berbeda nyata pada taraf 5\% Uji Duncan.

Tabel 4.10. Nilai Elongasi Edible Film dari Beberapa Variasi Pati Biji Alpukat.

\begin{tabular}{cc}
\hline Pati Biji Alpukat & Elongasi Edible film \\
\cline { 2 - 2 } & Rata-rata \\
\hline $10 \%$ & $11,2104^{\mathrm{b}}$ \\
$20 \%$ & $11,2104^{\mathrm{b}}$ \\
$30 \%$ & $12,5044^{\mathrm{b}}$ \\
$40 \%$ & $5,3167^{\mathrm{a}}$ \\
\hline
\end{tabular}

Keterangan : Nilai rata-rata yang ditandai dengan huruf yang sama menunjukkan tidak berbeda nyata pada taraf $5 \%$ Uji Duncan.

Cantherine (2004) dalam Amaliya dan Putri (2014).

\section{Uji elongasi}

Pengujian $\begin{array}{r}\text { elongasi } \\ \text { dilakukan untuk mengetahui } \\ \text { persentase } \\ \text { panjangnya bahan awal yang } \\ \text { diujikan, elongasi }\end{array}$ sendiri
merupakan seberapa besar
pertambahan panjang suatu
bahan ketika dilakukan adanya
kekuatan tari. Menurut (Akili et al.
2012) elongasi merupakan
perbandingan panjang film saat
putus dan panjang film sebelum
adanya beban berupa tarikan
yang dilakukan oleh alat. Adapun
hasil pengamatan uji elongasi
dapat dilihat pada Tabel 4.7

Semakin tinggi pati yang ditambahkan maka elongasi dari edible film memiliki sifat tidak mudah patah dan lebih elastis. Pati memberikan sifat struktur kompak pada edible film. Banyaknya penambahan pati pada proses pembuatan edible film menyebabkan ketebalan edible film, semakin meningkatnya ketebalan edible film akan menyebabkan elongasi meningkat pula. Pati dengan tingkat amilosa tinggi dan gliserol menyebabkan persen elongasi edible film tinggi (Amaliya dan Putri 2014). 


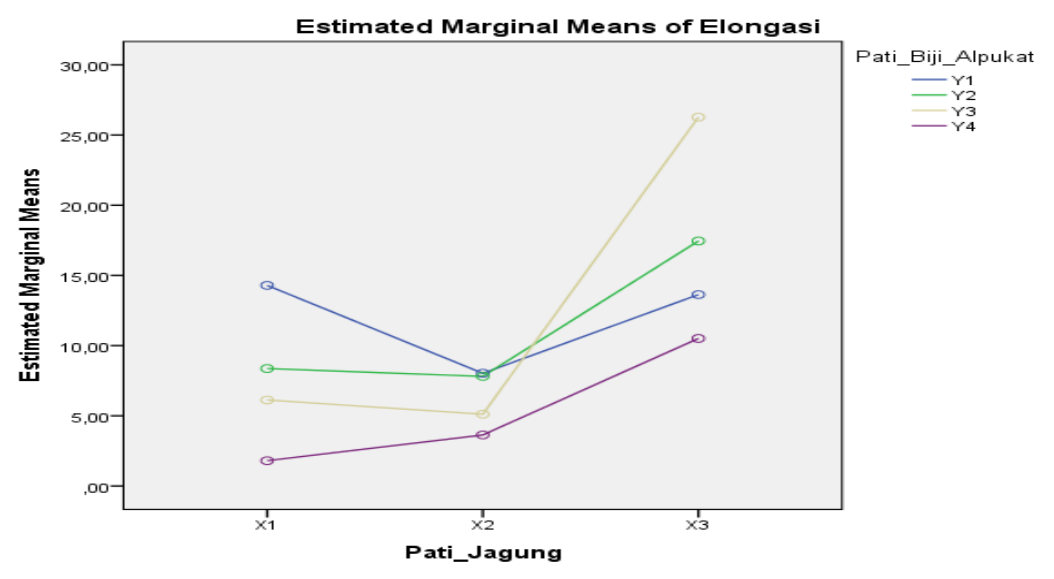

Gambar 4.6 Pati jagung*Pati Biji Alpukat

Gambar 4.6 menunjukkan bahwa penambahan pati jagung cenderung meningkatkan nilai elongasi edible film pati biji alpukat dan pati jagung. Pada pati jagung 4 gr dan pati biji alpukat $40 \%$ menunjukkan bahwa nilai elongasi antara $0,0-5,0 \%$, pati jagung $6 \mathrm{gr}$ dan pati biji alpukat $40 \%$ memiliki nilai elongasi lebih tinggi dari elongasi pati jagung $4 \mathrm{gr}$ dan pati biji alpukat $40 \%$, begitu pula pati jagung 8 gr dan pati biji alpukat $40 \%$ memiliki nilai elongasi antara $5,0-10,0 \%$.

\section{CPI (Composite Performance Index)}

Penentuan perlakuan terbaik menggunakan metode CPI untuk bobot ditentukan oleh pakar edible film, hasil CPI dapat dilihat pada Tabel 4.11 bahwa alternatif pati jagung $8 \mathrm{gr}+$ pati biji alpukat 2,4 $\mathrm{gr}$ merupakan peringkat pertama dengan nilai alternatif 395,34. Penggunaan pati jagung 6 $\mathrm{gr}+0,6 \mathrm{gr}$ pati biji alpukat memiliki peringkat lebih rendah dibandingkan sampel lain.

Tabel 4.11. Perlakuan Terbaik Edible Film Pati Biji Alpukat dan Pati Jagung.

\begin{tabular}{|c|c|c|c|c|c|c|}
\hline \multicolumn{2}{|c|}{ Komponen } & \multicolumn{3}{|c|}{ Kriteria } & \multirow{2}{*}{$\begin{array}{c}\text { Nilai } \\
\text { Alternatif }\end{array}$} & \multirow[b]{2}{*}{ Peringkat } \\
\hline $\begin{array}{c}\text { Pati } \\
\text { Jagung }\end{array}$ & $\begin{array}{l}\text { Pati Biji } \\
\text { Alpukat }\end{array}$ & Ketebalan & Kuat Tarik & Elongasi & & \\
\hline $4 \mathrm{gr}$ & $0,4 \mathrm{gr}$ & 62,16 & 100,00 & 392,67 & 213,46 & 5 \\
\hline $4 \mathrm{gr}$ & $0,8 \mathrm{gr}$ & 60,53 & 202,74 & 229,95 & 178,61 & 8 \\
\hline $4 \mathrm{gr}$ & $1,2 \mathrm{gr}$ & 56,10 & 206,48 & 168,32 & 152,86 & 12 \\
\hline $4 \mathrm{gr}$ & $1,6 \mathrm{gr}$ & 38,33 & 325,99 & 445,97 & 304,47 & 2 \\
\hline $6 \mathrm{gr}$ & $0,6 \mathrm{gr}$ & 92,00 & 124,09 & 220,60 & 156,60 & 11 \\
\hline $6 \mathrm{gr}$ & $1,2 \mathrm{gr}$ & 71,88 & 277,33 & 214,56 & 199,60 & 7 \\
\hline $6 \mathrm{gr}$ & $1,8 \mathrm{gr}$ & 71,88 & 276,70 & 140,48 & 168,28 & 9 \\
\hline $6 \mathrm{gr}$ & $2,4 \mathrm{gr}$ & 56,10 & 309,91 & 100,00 & 158,29 & 10 \\
\hline $8 \mathrm{gr}$ & $0,8 \mathrm{gr}$ & 100,00 & 106,19 & 374,54 & 217,35 & 4 \\
\hline $8 \mathrm{gr}$ & $1,6 \mathrm{gr}$ & 88,46 & 170,64 & 479,49 & 279,81 & 3 \\
\hline $8 \mathrm{gr}$ & $2,4 \mathrm{gr}$ & 74,19 & 223,25 & 721,70 & 395,34 & 1 \\
\hline $8 \mathrm{gr}$ & $3,2 \mathrm{gr}$ & 52,27 & 225,94 & 288,74 & 208,90 & 6 \\
\hline \multicolumn{2}{|c|}{ Bobot } & 0,25 & 0,33 & 0,42 & & \\
\hline
\end{tabular}




\section{PENUTUP}

\section{Kesimpulan}

Berdasarkan hasil penelitian maka disimpulkan:

1. Karakteristik fisik Edible film pada penggunaan pati jagung dan pati biji alpukat menghasilkan ketebalan $0,114 \mathrm{~mm}-0,125 \mathrm{~mm}$, kuat tarik $772,860 \quad \mathrm{~N} / \mathrm{cm}^{2} \quad$ $1018,233 \mathrm{~N} / \mathrm{cm}^{2}$, dan elongasi $9,032 \%-11,476 \%$.

2.Hasil pemilihan perlakuan terbaik menggunakan $\mathrm{CPI}$ didapatkan bahwa perlakuan pati jagung $8 \mathrm{gr}$ dan pati biji alpukat 2,4 gr menjadi perlakuan terbaik dengan nilai ketebalan $74,19 \mathrm{~mm}$, kuat tarik $223,25 \quad \mathrm{~N} / \mathrm{cm}^{2}$ dan elongasi $395,34 \%$.

\section{Saran}

Adapun saran untuk penelitian ini Perlu adanya uji pengaplikasian umur simpan menggunakan pengemas edible film pati biji alpukat dan pati jagung terhadap produk hasil pertanian dan Perlu adanya penelitian lanjut mengenai uji warna pada edible film pati biji alpukat dan pati jagung.

\section{DAFTAR PUSTAKA}

Akili M.S., Usman Ahmad, dan Nughraha E.S. 2012. Karakteristik Edibe Film dengan Pektin Ekstraksi dari Kulit Pisang. Jurnal Keteknikan Pertanian. 26(1) : 39-46.
Amaliya R.R. dan Widya Dwi R.P.,2014. Karekterisasi Edible Film Dari Pati Jagung Dengan Penambahan Filtrat Kunyit Putih Sebagai Anti Bakteri. Jurnal Pangan Dan Agroindustry.2(3) : 43-53.

Aulia Dewi N.H., Istiqomah, Siti S.R., 2014. Pengolahan Limbah Biji Alpukat Untuk Pembuatan Dodol Pati Sebagai Alternatif Pengobatan Ginjal. Jurnal Ilmiah Mahasiswa . 4(1) : 32-37.

Badan Pusat Statistik. 2014. Statistik Produksi Holtikultura Tahun 2014. Kementrian Pertanian.

Basuki E.K.S., Jariyah dan Dhenok D.H. 2014. Karakteristik Edible Film Ubi Jalar Dan Gliserol. J.REKAPANGAN.8(2) : 128-135.

Darmawan A. 2017. Optimasi Tensile Strength, Elongation Dan Permeabilitas Uap Air (Water Vapor Permeability) Pada Biodegradable Film Berbahan Dasar Pati Singkong Dan Tepung Gathotan. Skripsi. Fakultas Pertanian. Universitas Trunojoyo Madura. Bangkalan.

Dwimayasanti R. 2016. Pemanfaatan Karagenan Sebagai Edible Film. Oscana. 41(2) : 8-13.

Fajarini R.N., Soewarto H., dan Hardienata. 2015. Sistem 


$\begin{array}{lr}\text { Penunjang } & \text { Keputusan } \\ \text { Menggunakan } & \text { Metode } \\ \text { Composite Performance } & \text { Prorilihan } \\ \text { Index Untuk } & \text { Pemilihander } \\ \text { Pemenang } & \text { Tender } \\ \text { Pengadaan Barang/Jasa. } & \text { Bniversitas Pakuan. }\end{array}$

Fardhyanti D.S. dan Syara S.J. 2015. Karakterisasi Edible Film Berbahan ekstrak Karagenan Dari Rumput Laut (Eucheuma Cottonii).Jurnal Bahan Alam Terbarukan.4(2): 4856.

Jacoeb A.M., Roni Nugraha, Siluh P.S.D.U. 2014. Pembuatan Edible Film Dari Pati Buah Lindur Dengan Penambahan Gliserol Dan Karagenan. JPHPI. 17(1) : 14-21.

Krochta, J.M., De MulderJohnston, C., 1997, Edible and Biodegradable Polymer Films: Challenges and opportunities, J. Food Technol., 51(2) : 61-74.

Kusumawati, D. H. dan Widya D.R. P, 2013. Karakteristik fisik dan kimia edible film pati jagung yang diinkorporasi dengan perasan temu hitam, Jurnal Pangan dan Agroindustri. 1(1) : 90-100.

Lubis, L.M.2008. Ekstrasi Pati Dari Biji Alpukat. Departemen Teknologi Pertanian. Fakultas Pertanian. Universitas Sumatera Utara. Medan.

Maflahahlffan. 2010. Analisis Proses Pembuatan Pati Jagung (maizena) Berbasis
Neraca Massa. Jurnal EMBRYO. 7(1) : 216-188.

Maharani Y., Faizah Hamzah, dan Rahmayuni. 2017. Pengaruh Perlakuan Sodium Tripolyphosphate (STPP) Pada Pati Sagu termodifikasi Terhadap Ketebalan, Transparansi dan Laju Perpindahan Uap Air Edible Film. JOM FAPERTA.4(2) : 1-10.

Murni S.W., Harso P., Desi W., dan Novita S. 2013. Pembuatan Edible Film Dari Tepung Jagug (Zea Mays L.) Dan Kitosan. Prosiding Seminar Nasional Teknik Kimia "Kejuangan". ISSN 16934393.

McHaugh, T., J. F. Aujard dan J. M. Krochta. 1994 Plasticcized whey Protein Edible Film: WaterVapor Permeabelity Properties. Journal of Food Science, 59(423) : 416-419.

Milani, J., dan G. Maleki. 2012. Hidrocolloids in Food Industry. Ln : Valdez, B. (ED). Food Industrial Processe-Methods and Equipment; In Teach. Canada : 17-38.

Mindarwati, E., 2006. Kajian Pembuatan Edible Film Komposit dari Karagenan sebagai Pengemas Bumbu Mie Instant Rebus. Tesis. Program Studi Teknologi Pasca Panen, Institut Pertanian Bogor, Bogor: 83 hal.

Nur Aini Dan Nur Haeni, 2008. Komposisi Kimia Dan Sifat 
Fungsional Pati Jagung Berbagai Variates Yang Diekstrak Dengan Pelarut Natrium Bikarbonat. Jurnal Agroland. 15(2): 89-94.

Sara N. E. M..2015. Karakteristik Edible Film Berbahan Dasar Whey Dangke Agar dengan Penambahan Konsentrasi Sorbitol. Skripsi. Fakultas Peternakan. Universitas Hasanuddin Makasar Makasar.

Prasetyo A.E., Anggara Widhi, dan Widayat. 2012. Potensi Gliserol Dalam Pembuatan Turunan Gliserol Melalui Esterifikasi. Jurnal IImu Lingungan. 10(1): 26-31.

Purwanti A. 2010. Analisis Kuat Tarik dan Elongasi Plastik Kitosan Terplastisasi Slorbitol. Jurnal Teknologi. 3(2): 99-106.

Rahardiyanto T.P. dan Agustini R., 2013. Pengaruh Massa Gliserol Terhadap Titik Leleh Plastic Biodegradable Dan Pati Ubi Kayu, UNESA. Journal of Chemistry. 2(1) : 109113.

Rangkuti A.H. 2009. Metode Pengambilan Keputusan Secara Efektif Pada Kriteria Majemuk Dengan Metode Bayes, MPE, CPI dan AHP. Jurnal Basis Data. 4(1) : 95-104.

Robertson L.G. 1992. Food Packaging (Principlas and Practice) Marcel Deleker, Inc. New york.
Rusli A., Metusalach, Salengke, Mulyati Muhammad Tahir. 2017. Karakterisasi Edible Film Karagenan Dengan Pemlastis Gliserol. JPHPI. 20(2) : 219-229.

Santoso B., Herpandi, Puspa A.P., dan Rindit P., 2013. Pemanfaatan Karagenan dan Gum Arabic Sebagai Edible Film Berbasis Hidrokoloid. AGRITECH. 33(2) : 140-145.

Santoso R., 2016. Sistem Pendukung Keputusan Menentukan Penerima Beasiswa Menggunakan Metode Comprative Performance Index (CPI). Articel Skripsi. Universitas Nusantara PGRI Kediri.

Setiani W., Tety Sudiarti, dan Lena Rahmidar. 2013. Preparasi Dan Karakterisasi Edible film Dari Poliblend Pati SukunKitosan. 2(3) : 100-109.

Ulfah F, Nugraha,, I. 2014. Pengaruh Penambahan Montmorillonit Terhadap Sifat Mekanik Komposit Film KaragenanMontmorillonit. Jurnal IImiah Molekul. 9(2) : 154165.

Warkoyo, Rahardjo Budi, M.2014.Sifat Fisik, Mekanik dan Barier Edible Film Berbasis Pati Umbi Kimpul (Xanthosoma Sagitifiolium) Yang Diinkorporasi Dengan Kalium Sorbat. AGRITECH. 34(1) : 72-81.

Wattimena D., La Ega, dan Febby J.P., 2016. Karekterik 
Edible Film Pati Sagu Alami Dan Pati Sagu Fosfat Dengan Penambahan Gliserol. Jurnal Agritech. 36(3) : 247-252.

Yudiandani A., Raswen E., Ahmad I.. 2016. Pemanfaatan Biji Alpukat (Persea Americana Mill.)
Untuk Pembuatan Edible Film. Jurnal FAPERTA. 3(2) : 1-10.

Zulhida R. Dan Hery S.T. 2013. Pemanfaatan Biji Alpulkat (Persea Americana Mill.) Sebagai Bahan Pembuat Pati. AGRIUM. 18(2) : 144148 